\title{
Aurealcaulis crossii gen. et sp. nov., an arborescent, osmundaceous trunk from the Fort Union Formation (Paleocene), Wyoming
}

\author{
William D. Tidwell
}

Lee R. Parker

Follow this and additional works at: https://scholarsarchive.byu.edu/facpub

Part of the Geology Commons

\section{Original Publication Citation}

Aurealcaulis crossii gen. et sp. nov., an arborescent, osmundaceous trunk from the Fort Union Formation (Paleocene), Wyoming. William D. Tidwell and Lee R. Parker American Journal of Botany (June 1987), 74(6):83-812

\section{BYU ScholarsArchive Citation}

Tidwell, William D. and Parker, Lee R., "Aurealcaulis crossii gen. et sp. nov., an arborescent, osmundaceous trunk from the Fort Union Formation (Paleocene), Wyoming" (1987). Faculty Publications. 1447.

https://scholarsarchive.byu.edu/facpub/1447

This Peer-Reviewed Article is brought to you for free and open access by BYU ScholarsArchive. It has been accepted for inclusion in Faculty Publications by an authorized administrator of BYU ScholarsArchive. For more information, please contact ellen_amatangelo@byu.edu. 


\title{
AUREALCAULIS CROSSII GEN. ET SP. NOV., AN ARBORESCENT, OSMUNDACEOUS TRUNK FROM THE FORT UNION FORMATION (PALEOCENE), WYOMING ${ }^{1}$
}

\author{
William D. Tidwell and Lee R. Parker \\ Department of Botany and Range Science, Brigham Young University, Provo, Utah 84602, and \\ Biological Sciences Department, California Polytechnic State Univeristy, \\ San Luis Obispo, California 93407
}

\begin{abstract}
A B S T R A C T
Aurealcaulis crossii gen, et sp. nov., is based on permineralized trunks of an osmundaceous tree fern from the Paleocene Fort Union Formation from near Bitter Creek Station of southwestern Wyoming. This new species is characterized by centripetal (exarch) development of its xylem strands which form part of the leaf traces. Most of the leaf traces depart the stele as two segments that fuse into a single $\mathrm{C}$-shaped petiole vascular strand outside of the outer cortex. Stipular expansions of the petiole bases of this species lack sclerenchyma, and roots arise from the lateral edges of leaf traces in the inner cortex. The family Osmundaceae and subfamily Osmundoideae are slightly emended to accept genera assignable to this family and subfamily with exarch protoxylem in their steles. Foliage similar to Osmunda greenlandica (Heer) Brown, which is possibly the leaf form of $A$. crossii, occurred next to an axis of this species which was in growth position. This axis was anchored in a lignite suggesting that this species grew under swampy conditions. Aurealcaulis crossii is the first arborescent member of the Osmundaceae of Tertiary age and the second arborescent form in this family reported from the Northern Hemisphere.
\end{abstract}

TWENTY-SIX SPECIMENS of permineralized trunks constituting a new genus and species in the Osmundaceae were collected from the Fort Union Formation approximately 25 miles (40 $\mathrm{km}$ ) southeast of Rock Springs, Wyoming, and about 6 miles $(9.6 \mathrm{~km})$ southwest of Bitter Creek Station on the Union Pacific Railroad. These specimens consist of small stems surrounded by persistent, closely appressed petiole bases. The stem region of many of these specimens is not preserved and appears as an empty cylinder surrounded by leaf bases. However, those specimens with well-preserved stems were thinsectioned and studied. The collecting site for these specimens was strip-mined subsequent to collecting and, consequently, the site does not appear as it was when originally collected (Fig. 1, 2).

The majority of these permineralized fern axes occurred on the surface and were weathered from a vertical interval of $35 \mathrm{ft}(10.8 \mathrm{~m})$ at the collecting site. A few specimens were in situ in the thin-bedded, fluvial carbonaceous sediments from which they were removed. This interval includes five lignitic units which alternate with sandstones, siltstones, and shales. Primary sedimentary features in these rocks include thin laminar beds, crossbedding, ripple marks, tool marks, and lens-shaped channel

Received for publication 13 May 1986; revision accepted 24 September 1986. fills which had scoured bases. Compressions of fern pinnules, dicotyledonous leaves and stem fragments occurred in many of the finergrained sediments. Numerous vertical in situ stem or root compressions were also observed. All the permineralized trunks, collected on the surface of the slope, had apparently weathered from different horizons within the $10.8 \mathrm{~m}$ unit.

The geology of the Fort Union Formation, in this area, was summarized by Winterfeld (1982) who noted that a maximum of $1,800 \mathrm{ft}$ $(549 \mathrm{~m})$ of sedimentary strata referred to the Fort Union Formation is exposed on the eastcentral flank of the Rock Springs Uplift in Sweetwater County, Wyoming. The Fort Union Formation in this area is unconformably underlain by the Upper Cretaceous Lance Formation and overlain by the Early Eocene Wasatch Formation. The base of the section is a distinctive paleosol or thick sandstone horizon and Winterfeld considered the eastern-most occurrence of the limestone and sandstonecapped cuestas as the most convenient place to mark the uppermost beds of the local Fort Union Formation.

Winterfeld (1982) described fifty-two mammalian species recovered from nineteen new fossil vertebrate sites in the Fort Union Formation near the collecting locality for Aurealcaulis. He noted that fossil plants were common throughout the section. Leaf compressions and lignitized and silicified tree trunks occur 


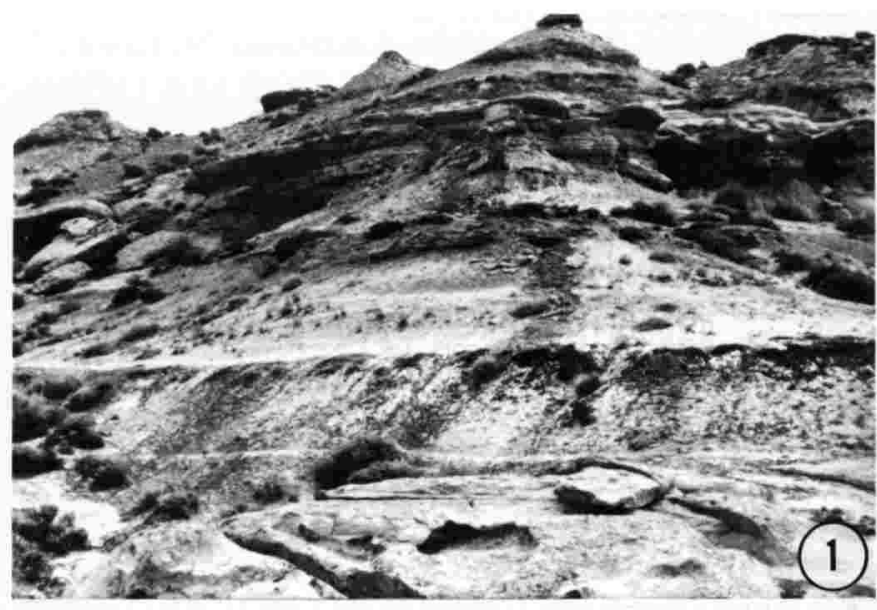

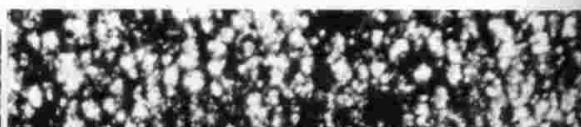
cos.s.

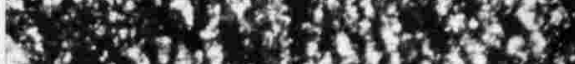

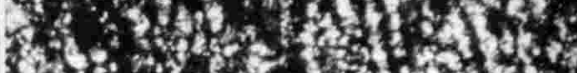

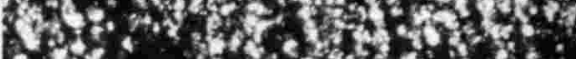

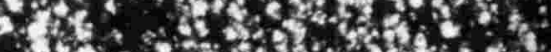
s.t.

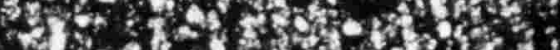
H.t.

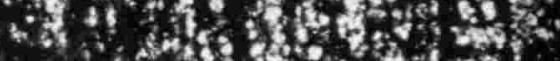

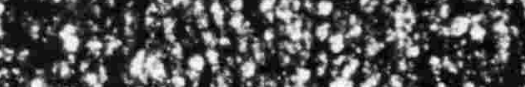

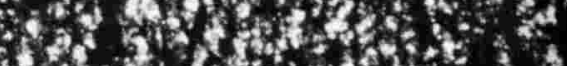

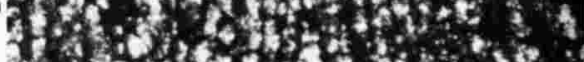

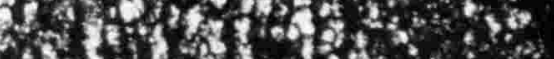

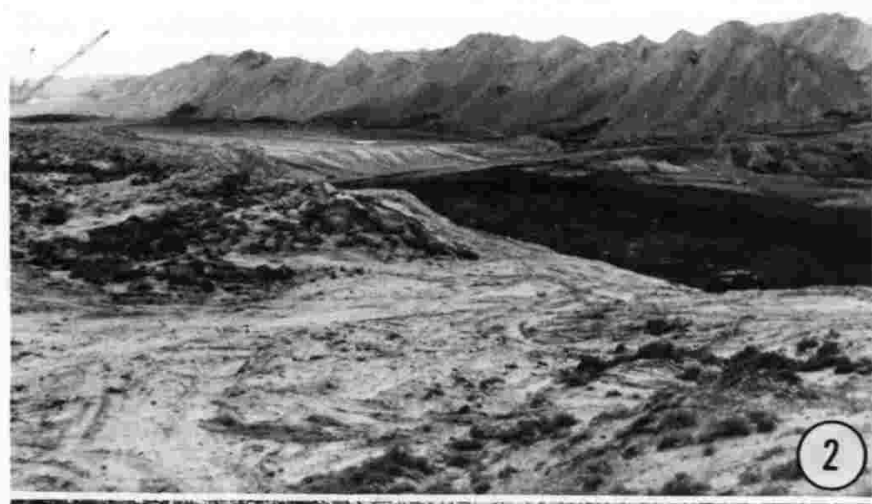

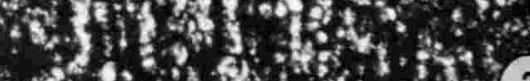

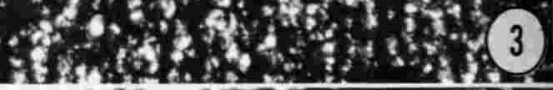

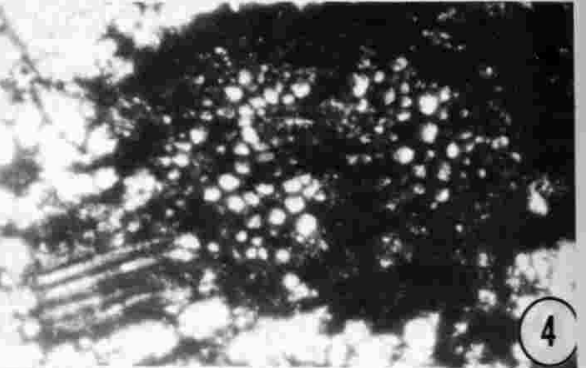

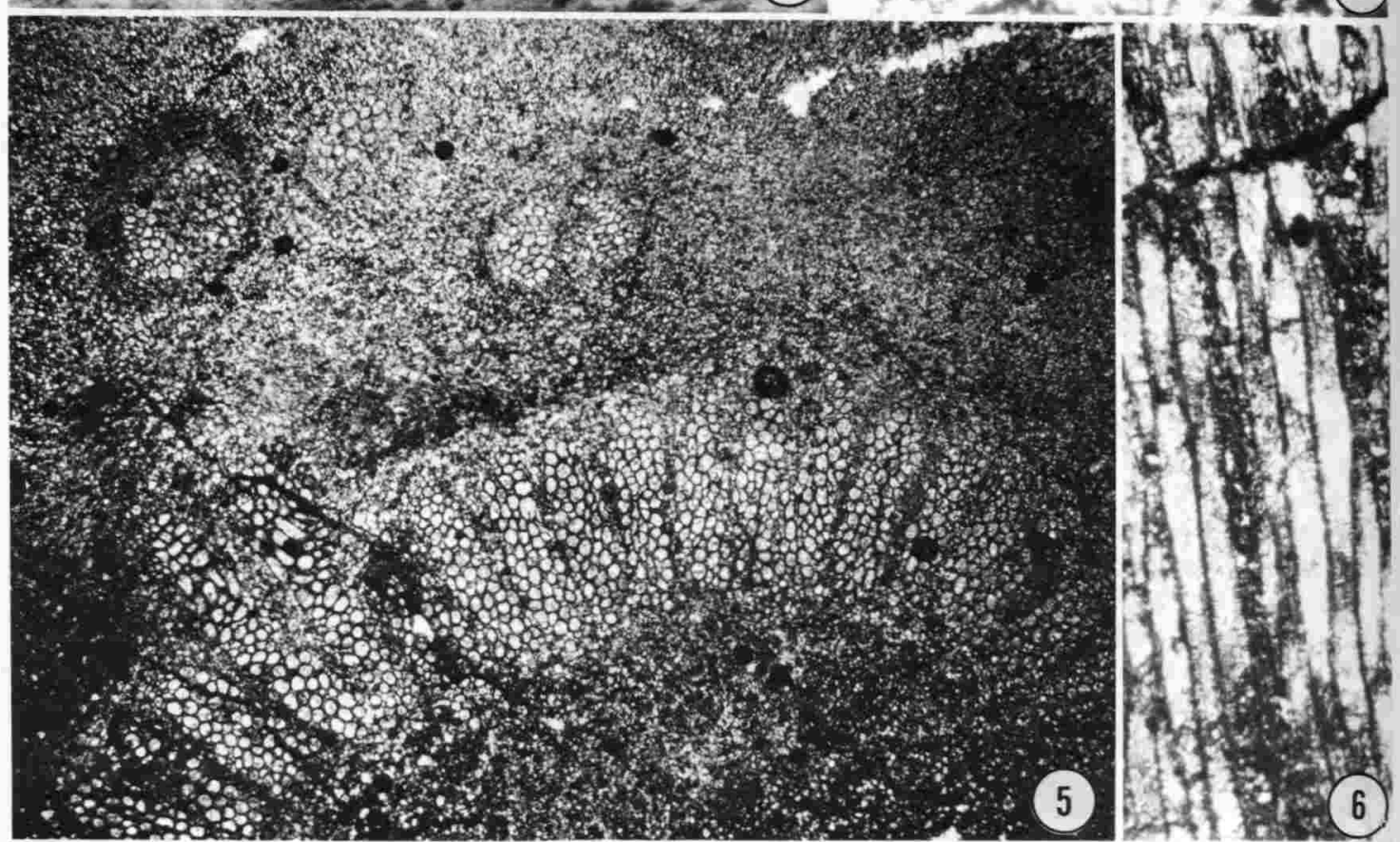

Fig. 1-6. 1. Collecting site as it appeared during initial collecting. Specimens were collected in the sandstones, shales and lignites in the upper one third of this ridge. 2. Appearance of locality after strip-mining one year later. 3. Longitudinal 
in the limestones, mudstones, shales, coals, sideritic beds and channel sandstones that comprise this formation (Fig. 1, 2).

Associated with specimens of this new osmundaceous genus were compressional fossils of Glyptostrobus Endl. and pinnules of Allantodiopsis erosa (Lesq.) Knowlton and Maxon. One specimen of the new genus was observed in growth position anchored in a lignite bed (Fig. 8). This in situ axis of $A$. crossii was about three $\mathrm{ft}(91.5 \mathrm{~cm})$ in length and its upper and lower portions were lignified although its center section was permineralized with the typical rind of persistent leaf bases. This trunk extended above the lignite unit approximately 2 to 4 inches $(5$ to $10 \mathrm{~cm}$ ). This portion of the trunk was surrounded by thin, interbedded sandy siltstones and shales which contain numerous specimens of osmundaceous foliage. These observations suggest that this individual plant was rooted, as a living plant, in a swamp surface. Several feet of peat (now about two $\mathrm{ft}$ [61 cm] of lignite) had already accumulated in this portion of the swamp. The flooding of a local river, which poured several $\mathrm{cm}$ of silt and clay into this swamp area, appears to have pushed this fern onto its side, leaving it inclined at about $45^{\circ}$. This displacement does not appear to have killed the plant for during its slow burial, it continued to produce foliage which was regularly incorporated in the sediment. The growth of the stem apex eventually redirected the upper portion of this trunk from an inclined to a vertical position. The broad falcate pinnules of the osmundaceous fronds immediately adjacent to this axis are separated from one another by narrow, rounded sinuses (Fig. 12, 18). Their secondary veins are openly spaced, divided once near the midvein and rarely divide again, although they may do so occasionally near the pinnule margins. The leaves closely resemble Osmunda greenlandica (Heer) Brown that were reported by Brown (1962) from the Fort Union Formation at various localities in Montana and near Rifle, Colorado. No fertile fronds were found.

The size of the specimens of this new taxon varies from small water worn trunks about two inches $(5 \mathrm{~cm})$ in diameter to one that is two feet $(61 \mathrm{~cm})$ across. The longest specimen is six $\mathrm{ft}(1.8 \mathrm{~m})$ long by one $\mathrm{ft}(30 \mathrm{~cm})$ wide (Fig. 7). The latter specimen appears to be eroded but does not taper at either end, suggesting that it was much taller when living. The stems in these specimens are very small; consequently, most of the structure of these axes is due to the persistent petiole bases (Fig. 15). The widest specimen is two $\mathrm{ft}(61 \mathrm{~cm})$ in diameter.

Systematics SECTION-Family Osmundaceae emend.

Diagnosis-same as Miller (1971, p. 125) except where he stated, "leaf traces near point of attachment to stele mesarch or endarch," emend to: mesarch, endarch, or exarch.

Subfamily Osmundoideae emend.

Diagnosis-same as Miller (1971, p. 126) except where stated that "leaf-trace endarch or rarely subendarch at its base," change to: xylem strand and/or leaf trace endarch, mesarch and exarch becoming subendarch to endarch outward from the stele.

Genus Aurealcaulis gen. nov.

Diagnosis-Fossil osmundaceous rhizomes, arborescent or erect axes, surrounded by a mantle of leaf bases and adventitious roots; dissected ectophloic siphonostele or ectophloic dictyostele; xylem cylinder 10 or more tracheids thick, high number xylem strands, leaf gaps delayed, high, and wide; pith parenchymatous; cortex differentiated into inner and outer tissues; leaf traces often found in two segments, adaxially curved, protoxylem exarch, becoming endarch outside stem; petioles stipulate, sclerotic ring homogeneous, composed of fibers; stipular wings without sclerenchyma; roots diverge from leaf traces in inner cortex.

Generitype: $A$. crossii.

Aurealcaulis crossii sp. nov. (Fig. 3-26).

Diagnosis-Trunk arborescent, stem 16-27 $\mathrm{mm}$ in diameter, surrounded by a thick mantle of leaf traces and roots; stele 9-10 mm across, dissected ectophloic siphonostele; pith 5-6 mm in diameter, parenchymatous; xylem cylinder dissected, 2-3 mm wide, 15-21 tracheids thick radially, 50-60 (generally 55) xylem strands separated by leaf gaps, protoxylem exarch; phloem external; inner cortex 0.7-2 mm thick, mostly thin-walled parenchyma; outer cortex 3.5-4 mm wide; $28-30$ leaf traces per transverse section of cortex; departing leaf trace most often composed of two segments which fuse into a single $\mathrm{C}$-shaped petiole vascular strand

view of cells of outer cortex $(5030 \# 3 \mathrm{~b}) . \times 25$. 4. Transverse section of leaf trace with root trace departing at lower left $(5030 \# 1)$. $\times 25$. 5. Transverse section of a portion of the stem $(5030 \# 1)$. Note the separate segments of traces. $\times 12$. 6. Longitudinal section through a xylem strand showing tracheids $(5030 \# 3 \mathrm{~b}) . \times 25$. 

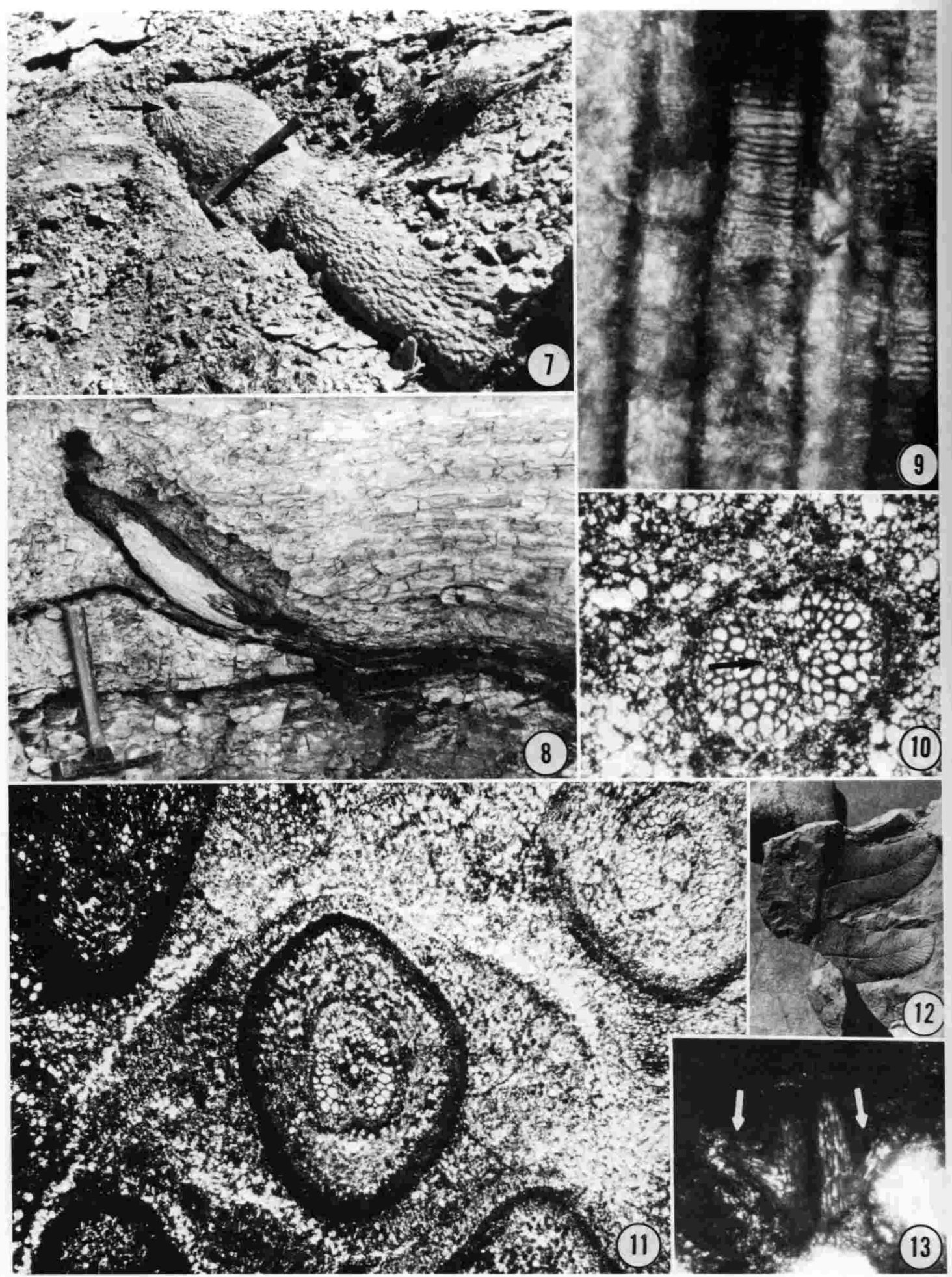

Fig. 7-13. 7. Specimen in situ illustrating large size and numerous persistent leaf bases. The small opening at the upper left of the specimen (arrow) represents the remainder of the stem at its basal end (hammer for scale) (5031). 8. Specimen in growth position that is anchored in a lignite bed (5032). Leaves were collected from sediments surrounding this axis (hammer for scale). 9. Longitudinal view of tracheids showing scalariform pitting $(5030 \# 3 \mathrm{~b}) . \times 75$. 10. Transverse view of leaf trace in inner cortex (abaxial side up; arrow indicates protoxylem $(5030 \# 1)$. $\times 25$. 11. Transverse 
outside outer cortex; traces sometimes distorted by crowding outside stem. Stipular wings of petiole bases lacking sclerenchyma; roots arising from lateral edges of leaf traces in inner cortex.

Repository: Brigham Young University 5030 (Holotype); 5031, 5032, 5033, 5034 (paratypes).

Locality: SW $1 / 4$ SE $1 / 4$ Sec. 21 T18N R100W Sweetwater Co., Wyoming Black Butte Quad.

Horizon: Fort Union Formation.

Age: Paleocene.

Derivation of name: This genus and species are both named for Professor Aureal T. Cross, Department of Geology, Michigan State University, East Lansing, Michigan in honor of his retirement and for his many contributions to paleobotany, palynology, and coal geology.

DESCRIPTION - The pith consists of parenchyma cells that are 40 to $60 \mu \mathrm{m}$ in size. These cells are thin-walled and are often distorted. In some regions of the pith, the walls of the parenchyma cells have disintegrated obscuring the individual cells. They may also contain dark contents. In certain areas, the pith cells have been destroyed and replaced by large, irregular to hexagonal crystalline material.

The stele is a dissected ectophloic siphonostele (Fig. 25). In most specimens only the xylem cylinder is preserved (Fig. 5). The remainder of the stelar tissues such as the xylem sheath, phloem, pericycle and endodermis are not often preserved. These tissues are usually crushed or replaced with crystalline material.

The dissected xylem cylinder is $2-3 \mathrm{~mm}$ across containing 55 xylem strands [ 40 strands by Hewitson's (1962) method of counting]. The xylem strands have a radial thickness of 1521 tracheids and are 4-5 tracheids wide. The metaxylem tracheids of these strands have multiseriate, scalariform pitting in their walls (Fig. 6, 9, 20) and are 40-175 $\mu \mathrm{m}$ in diameter by $135-245 \mu \mathrm{m}$ long. The protoxylem elements are $30-50 \mu \mathrm{m}$ wide. The protoxylem clusters are exarch on the distal portion of each of the xylem strands (Fig. 5, 17, 19, 20, 21, 24).

Complete leaf gaps occur between adjacent xylem strands, although a few incomplete gaps with distal openings are also present.

Leaf traces form in two ways in this species. The first and most common method of de- velopment occurs when the exarch protoxylem clusters on separate, but adjacent strands, face each other (Fig. 19) and with connecting metaxylem tissue split off, forming two distinct segments of the C-shaped trace. These segments remain separated until outside of the outer cortex where they fuse into a single C-shaped petiole vascular strand (Fig. 10,16). Most of the petiole vascular strands are C-shaped, although some appear nearly round (Fig. 10, 16).

The other method of trace formation is rare and occurs as the pocket elongates, splitting two previously fused xylem strands (Fig. 17). These strands separate and their tips then fuse on the cortical side of the strands. The U-shaped trace thus formed remains intact as it departs the xylem of the stele in contrast to the other method of formation. This type of leaf trace formation is similar to the "delayed gap" type (Miller, 1971). Two protoxylem clusters remain throughout much of the length of the petiole vascular strand. However, these clusters eventually divide to form four protoxylem points in the petiole strand.

In longitudinal view, some metaxylem tracheids that are larger than those next to them are $\mathrm{Y}$-shaped at the point of trace departure. One side of these tracheids remains as part of the xylem strand, whereas the other side becomes part of the trace (Fig. 22, 23).

No xylem sheath was preserved. It is usually crushed.

The phloem is external to the xylem and is rarely preserved. Where phloem cells are still present, they are $50-110 \mu \mathrm{m}$ in diameter. These form radial files of 2-4 cells.

The endodermis is not well preserved and appears to be marked by a broken line of cells filled with some type of dark contents.

The inner cortex is composed of parenchymatous tissue. The cells of this tissue are 40$115 \mu \mathrm{m}$ in diameter. Leaf traces in the inner cortex usually are comprised of two segments and are surrounded by cortical cells, as well as a weak endodermis, as it leaves this tissue. Some areas of the inner cortex are crushed, whereas many of its cells have dark contents.

Small, elongated, blocky cells with thin secondary walls characterize the outer cortex of this species (Fig. 3). Larger cells are scattered throughout this tissue. The small cells are 20$40 \mu \mathrm{m}$ across by $90 \mu \mathrm{m}$ long. Some portions

section of petiole showing stipular wings $(5030 \# 1) . \times 10.12$. Two pinnules of pinna of probable Osmunda greenlandica associated with Aurealcaulis crossii illustrating attachment of pinnules to rachis, and pinnule shape (figured specimen 5035). $\times 1$ 13. Longitudinal section through the two segments of a leaf trace with a root trace departing from each segment (arrows) $(5030 \# 3 \mathrm{~b}) . \times 25$. 


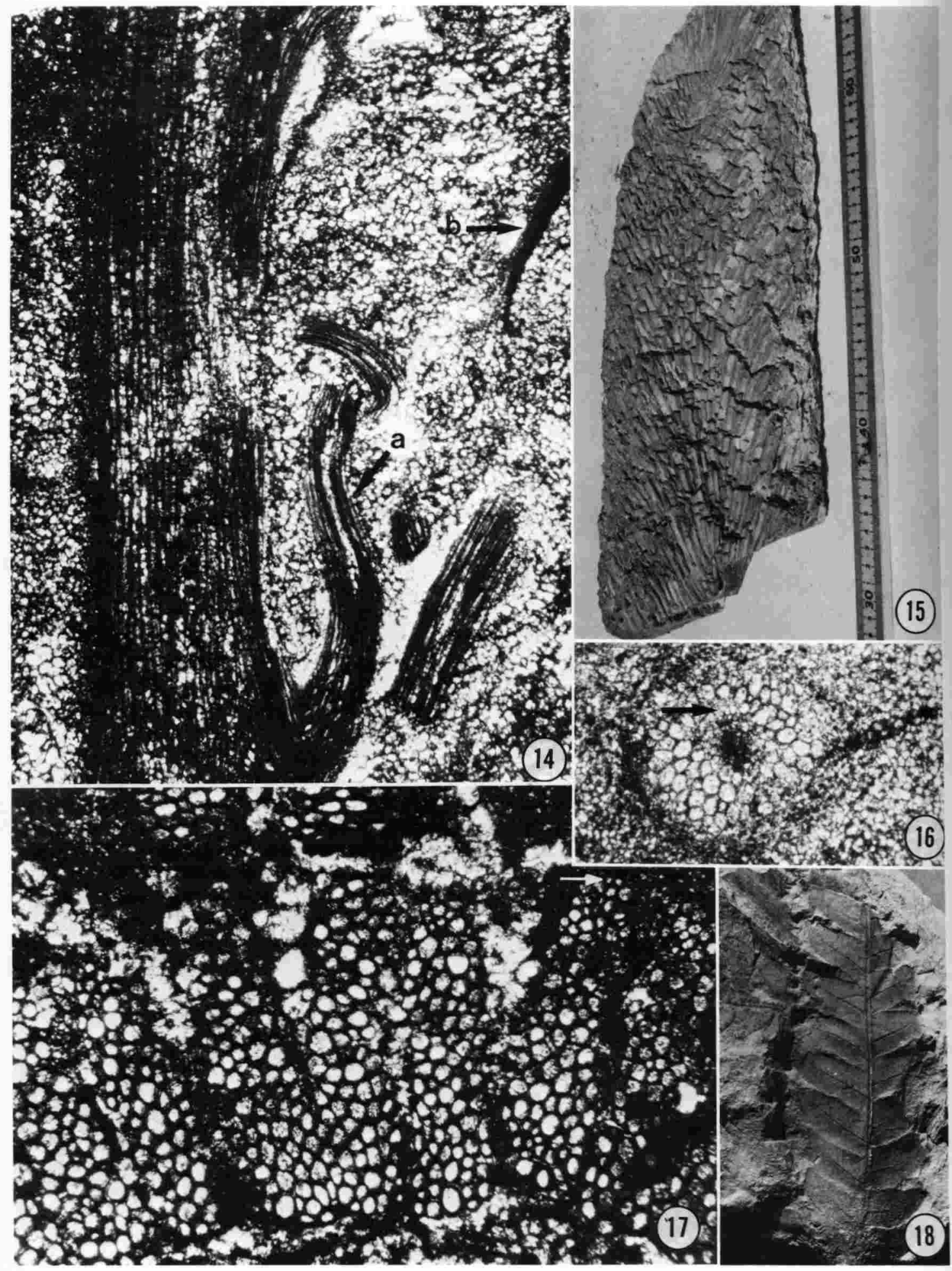

Fig. 14-18. 14. Longitudinal section through a xylem strand showing a trace departing and turning upward (a). Pith is on left and cortical layers are to right. Note beginning of the fibrous sclerotic ring in upper right (b) $(5033)$. $\times 20$. 15. Specimen showing the composition of the axis and the high angle of the attached petiole bases (5034). 16. Transverse section of leaf trace in which the two segments have fused on their abaxial sides (arrow indicates protoxylem (5030 
of this cortex are not preserved and are filled with crystals. The two segments of the leaf trace fuse in the outer cortex to form a continuous trace. The fibers of the sclerotic ring of the trace begin in this tissue and continue up the petiole base (Fig. 14). These fibers are elongated and tapering and are unlike the cells of the outer cortex.

There appear to be $28-30$ leaf traces in a transverse section of the cortices suggesting very short internodes in this species. Hewitson (1962) also partly accounted for the relatively high numbers of traces in Osmunda cinnamomea L. (11-27) and O. claytoniana L. (15$20)$ by the relatively steep inclination $\left(15-25^{\circ}\right)$ of the traces separating from the stele. This angle appears to be about $17^{\circ}$ in $A$. crossii. After the traces enter the cortex in $A$. crossii, however, they often turn upward forming a steeper angle with the stele (Fig. 14).

Passing from the stele towards the periphery of the axis, both the leaf trace and petiole vascular strand undergo a sequence of changes. The xylem in each side of the emerging segments of the trace is generally four to five cells thick and is composed of tracheary elements without parenchyma. Phloem appears to be abaxial. A layer of cells, which contains a dark substance, form a continuous layer around the trace. This layer probably constitutes the endodermis.

Cortical cells surround the leaf trace as it leaves the inner cortex. These cells are blocky in shape and many are filled with some type of dark cell contents.

A sclerotic ring forms around the trace near the outermost layers of the outer cortex. This ring is composed of fibers that are not continuous downward with the other tissues of the stem. Near the outer edge of the outer cortex, the sclerotic ring is $1.5 \mathrm{~mm}$ in diameter and at a later stage, it attains a diameter of approximately $3.0 \mathrm{~mm}$. At this later stage, the ring is about $0.2 \mathrm{~mm}$ in thickness. The cells comprising this ring are generally uniform in size $(50-70 \mu \mathrm{m}$ in diam.) and wall thickness $(10-25 \mu \mathrm{m})$. However, a layer of fibers near the edge of the sclerotic ring is much thickerwalled and appears to be more resistant to decay than the remainder of the ring.

The stipular expansions of the petiole bases lack sclerenchyma (Fig. 11). These expansions are often not preserved and generally distorted as are the petiole vascular strands by crowding of roots and adjacent, closely appressed, petiole bases. The stipular expansions vary in size from 5 to $6 \mathrm{~mm}$ from tip to tip. The parenchyma cells of the stipular wings are 50 to $90 \mu \mathrm{m}$ in diameter and, like the parenchyma cells of other tissues of the stem, are filled with dark contents. The epidermal cells of the wings measure $10 \mu \mathrm{m}$ in width by $20 \mu \mathrm{m}$ in tangential length and are much smaller than the other cells of this tissue. The cuticle is very thin. No sclerenchyma occurs in the adaxial concavity of the petiole vascular strand.

The roots are protostelic and diverge directly from the leaf traces in the inner cortex (Fig. 4). They were not observed separating from the traces at any other point of the axis (Fig. 13). The roots are exarch, diarch and are surrounded by the phloem, pericycle and endodermis, which are usually crushed, and by the cortices. The cells of the cortices of the roots are similar to those of the inner and outer cortices of the stem. The thick-walled fibers of the sclerotic ring of petioles are not present in the roots. The majority of the roots are cut transversely, which suggests that they grew vertically in the axis and, thus, provides additional evidence for an arborescent growth habit for this species (Miller, 1971).

Discussion-Aurealcaulis is proposed as a new genus in the Osmundaceae. However, since it has exarch primary xylem, Aurealcaulis cannot be assigned to the Osmundaceae and the subfamily Osmundoideae as they are presently defined (Miller, 1971). To erect a new family and subfamily to encompass these forms when all of their other features meets the familial and subfamilial descriptions seems unnecessary. Therefore, the family Osmundaceae and subfamily Osmundoideae are emended in this report to include taxa with exarch protoxylem in their stems and/or leaf traces.

Aurealcaulis is separated from members of the subfamily Thamnopteroideae by having siphonostelic rather than protostelic stems and, thus, is assigned to the subfamily Osmundoideae.

Aurealcaulis differs from the other genera within the family by various anatomical features. It is similar to Millerocaulis Erasmus ex

\#1). $\times 25$. 17. Transverse view of xylem strands of stele and leaf trace development (arrow) (5030 \#2). Note the protoxylem points (arrow) $\times 25$. 18. A portion of a pinna of probable Osmunda greenlandica found associated with the in situ axis (Figured specimen 5036). $\times 1$. 

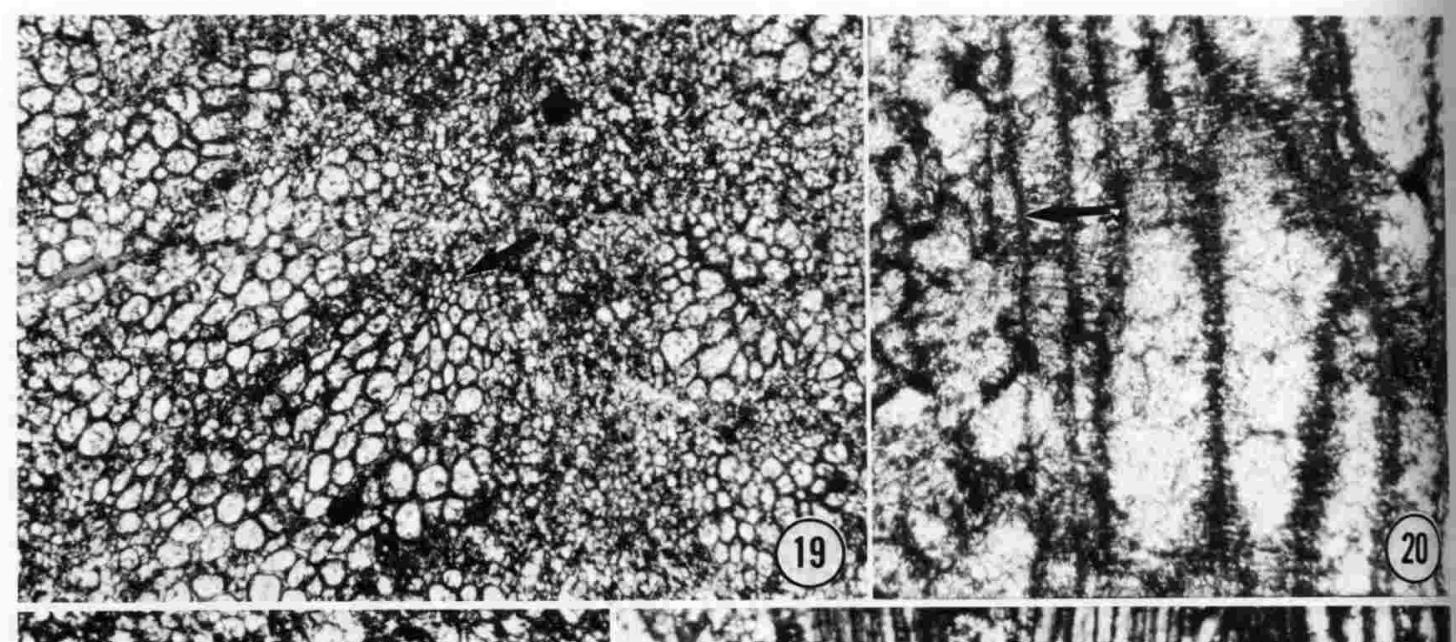

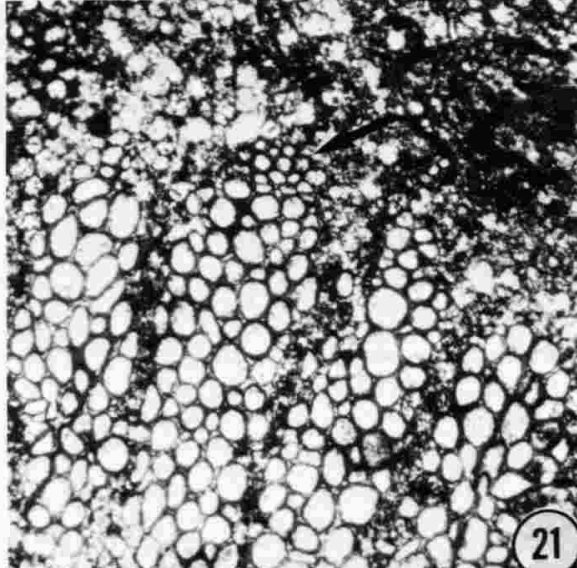

- +00007 721

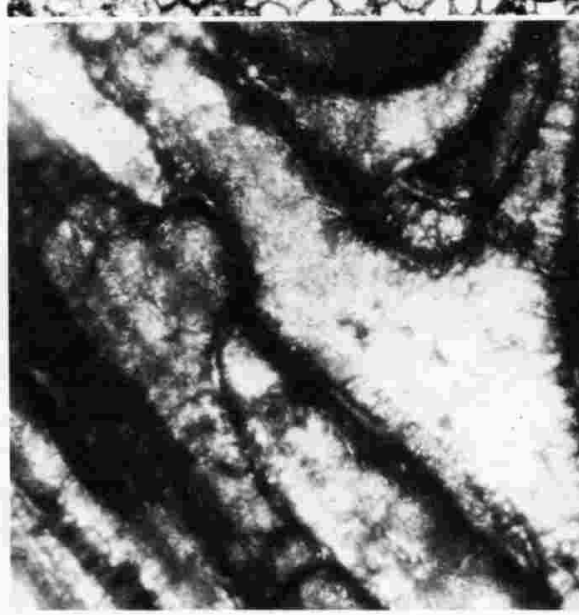

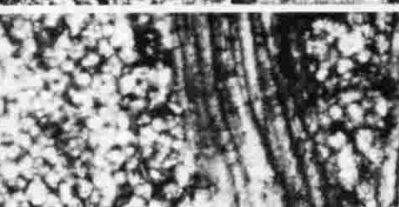

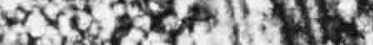

\section{tiv $2 \times 3$}

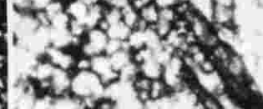

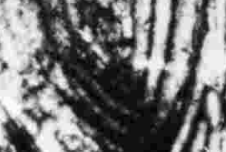
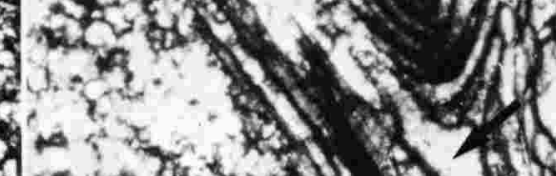
Tidwell (1986) in having two protoxylem clusters in its leaf traces. However, it is different from Millerocaulis in that the two protoxylem points in the latter genus originate from a division of a single mesarch cluster which does not occur in Aurealcaulis.

Aurealcaulis is similar to most species of Osmundacaulis (sensu stricto) in being arborescent, but it differs from both the latter genus and Millerocaulis in the manner of its leaf trace formation, in the different cellular composition of its cortex and in the lack of sclerenchyma in its stipular wings. Osmundacaulis natalensis (Schelpe) Miller and $O$. atherstonei (Schelpe) Miller from the Lower Cretaceous of South Africa also lack sclerenchyma in their stipular wings and are, therefore, similar in this feature of Aurealcaulis. Further, Aurealcaulis is unlike all other members of the Osmundaceae in having roots that arise directly from the trace and in having exarch xylem strands.

The foliage assigned to Osmunda (O. greenlandica and $O$. macrophylla Penhallow) by Brown (1962), the three structurally preserved species of Osmunda reported by Miller (1967, 1971), and Aurealcaulis crossii comprise the presently known osmundaceous flora of the Fort Union Formation. The three rhizomatous species, Osmunda pluma Miller, $O$. precinnamomea Miller and $O$. arnoldii Miller, are from Morton County, North Dakota (Miller, 1967, 1971). They differ from Aurealcaulis crossii mainly by their being rhizomatous and having endarch primary xylem rather than being arborescent and having exarch development as in $A$. crossii. Further, they have sclerenchyma in both the concavity of their traces and in the expansions of their stipular wings which is lacking in $A$. crossii.

The other arborescent form known from North America is Osmundacaulis skidegatensis (Penhallow) Miller, from the Lower Cretaceous of Queen Charlotte Islands, British Columbia. Osmundacaulis skidegatensis is dictyostelic and the stem is larger than the stem of Aurealcaulis crossii. The British Columbia species has an internal and external phloem and endodermis that are not present in the Wyoming specimens. Further, O. skidegatensis has sclerenchyma in the concavity of its traces and stipular wings that is lacking in $A$. crossii.

How Aurealcaulis crossii relates to the phylogeny of the Osmundaceae is uncertain at this time. It probably represents a discontinuation of an arborescent line that most likely had its origin in a presently unknown species of $O s$ mundacaulis (sensu stricto). However, Brown (1962) considered Osmunda greenlandica to

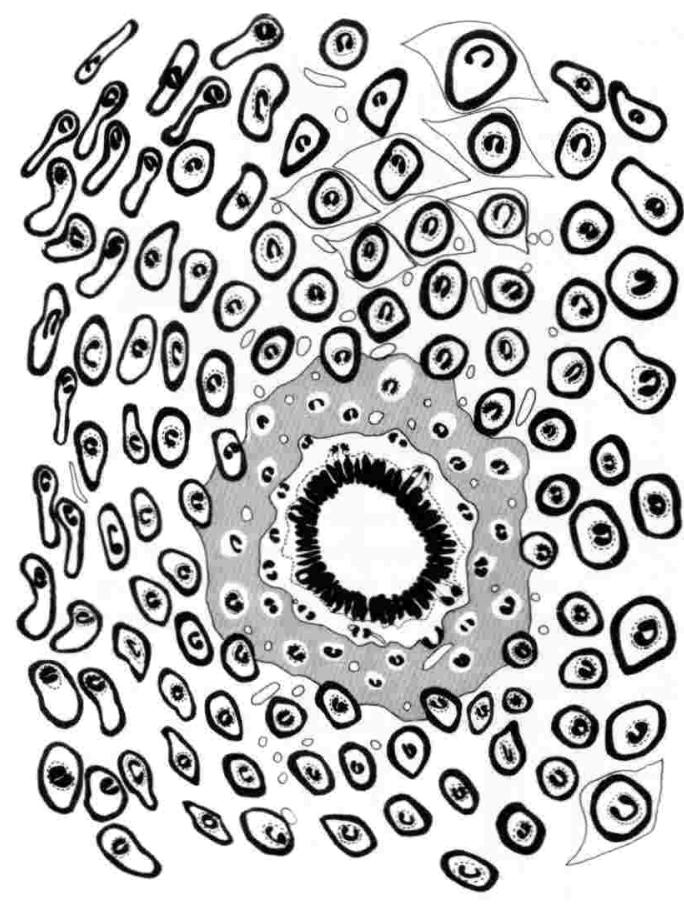

Fig. 25. Transverse section of an axis. Xylem = black, oblique strands forming traces $=$ dotted lines, endodermis = dashed outer line, outer cortex = light stipple, fibrous sclerotic ring $=$ darker stipple, roots $=$ open circles. $\times 2.5$.

be comparable to $O$. claytoniana $\mathrm{L}$. Although anatomically $O$. claytoniana is similar to $A$. crossii in having a wide outer- and thin innercortex and a high number of traces in its cortices (Hewitson, 1962), the rhizomes of O. claytoniana are very different from the arborescent stems of $A$. crossii and, therefore, there does not appear to be any definite relationship between them.

Development of the sclerotic ring and the composition of the outer cortex in $A$. crossii are similar to those in Todea and Leptopteris. Like $A$. crossii, the outer cortices of these latter two genera are composed of two cell types (Hewitson, 1962). The thick-walled fibers in the sclerotic rings surrounding the leaf traces in their outer cortices is considered one cell type and the second is the thinner-walled sclerenchyma with large lumina composing the basic outer cortical tissue in these genera. However, Todea and Leptopteris differ from Aurealcaulis in that leaf traces in the former genera contain a single protoxylem cluster that bifurcates in their respective outer cortices and the stipular expansions of their leaf bases contain sclerenchyma which is not present in $\mathrm{Au}$ realcaulis. 


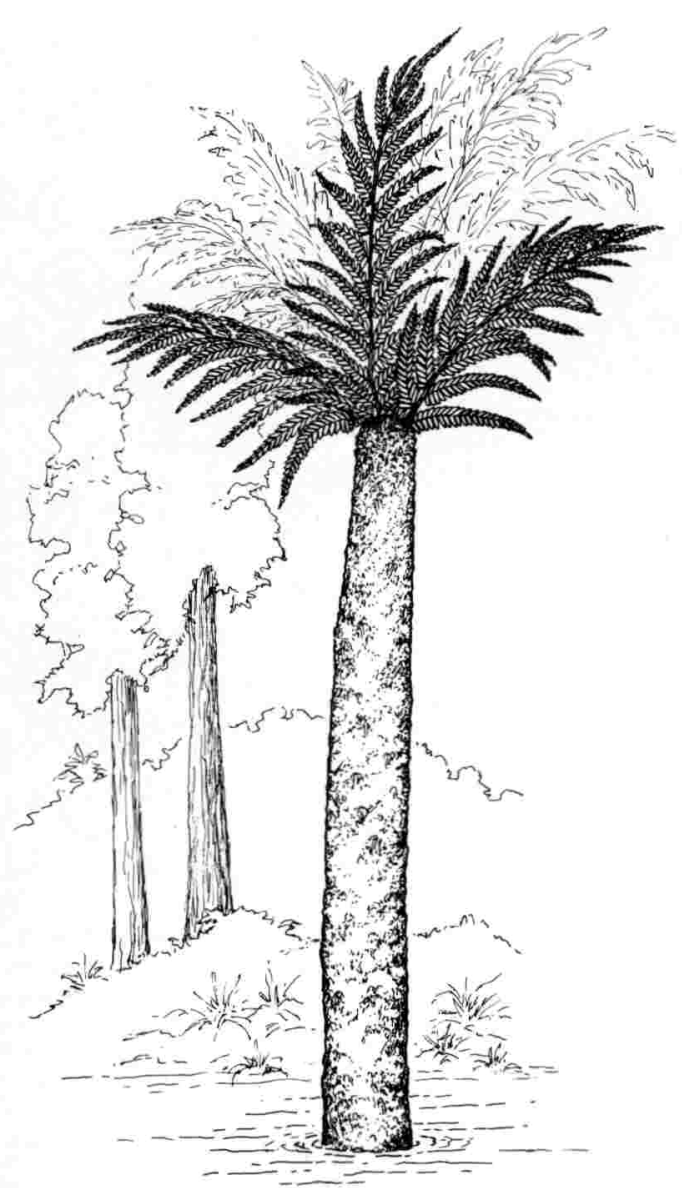

Fig. 26. Reconstruction of Aurealcaulis crossii gen. et sp. nov.

The axis of Aurealcaulis crossii collected in growth position with its base in a lignite bed (Fig. 8) indicates that at least some individuals grew in swamps that were part of the depositional environment of this formation (Fig. 26). The environment of the area where Aurealcaulis crossii occurred appears to have been a forest that grew under swampy conditions on a flat flood plain at not more than 900 to 1300 $\mathrm{ft}$ above sea level (Roehler, 1979). The alluvial plain was reworked by slow, meandering streams that frequently overflowed forming low levee and backswamp paludal deposits. These deposits include sideritic beds that often contain plant remains (Tidwell, Thayn, and Roth, 1976). Roehler (1979) suggested that strata of the Fort Union Formation in the general area where $A$. crossii was collected were deposited in a subtropical climate, whereas Brown (1962) considered the climate at this time to be mesophytic in a warm-temperate environment with a medium amount of precipitation distributed throughout the year. Such growing conditions in either climatic regime would have been appropriate for living Osmunda (Miller, 1967) and have been excellent for Aurealcaulis crossii as well.

\section{LITERATURE CITED}

BRown, R. 1962. Paleocene flora of the Rocky Mountains and Great Plains. U.S. Geol. Surv. Prof. Paper 375: 1-119.

Hewitson, W. 1962. Comparative morphology of the Osmundaceae. Ann. Missouri Bot. Gard. 48: 57-93.

Miller, C. N. 1967. Evolution of the fern genus Osmunda. Contr. Mus. Paleontol. Univ. Michigan 21(8): 139-203.

-1971. Evolution of the fern family Osmundaceae based on anatomical studies. Contr. Mus. Paleontol. Univ. Michigan 28(8): 105-169.

ROEHLER, H. W. 1979. Geological and energy resources of the Sand Butte Rim NW Quadrangle, Sweetwater County, Wyoming. U.S. Geol. Surv. Prof. Paper 1065 A: A1-A54.

TIDwell, W. D. 1986. Millerocaulis, a new genus with species formerly in Osmundacaulis Miller (fossils: Osmundaceae). Sida 11: 401-405.

- G. F. ThaYN, AND J. L. Roth. 1976. Cretaceous and Early Tertiary floras of the Intermountain Area. Brigham Young Univ. Geol. Studies 22: 77-98.

WinterFeld, G. F. 1982. Mammalian paleontology of the Fort Union Formation (Paleocene), Eastern Rock Springs Uplift, Sweetwater County, Wyoming. Contrib. Geol. Univ. Wyoming 21(1): 73-112. 